\title{
GENOMICS AND THE ARK an ecocentric perspective on human history
}

Citation for published version (APA):

Zwart, H., \& Penders, B. (2011). GENOMICS AND THE ARK an ecocentric perspective on human history. Perspectives in Biology and Medicine, 54(2), 217-231. https://doi.org/10.1353/pbm.2011.0019

Document status and date:

Published: 01/01/2011

DOI:

10.1353/pbm.2011.0019

Document Version:

Publisher's PDF, also known as Version of record

Document license:

Taverne

Please check the document version of this publication:

- A submitted manuscript is the version of the article upon submission and before peer-review. There can be important differences between the submitted version and the official published version of record.

People interested in the research are advised to contact the author for the final version of the publication, or visit the DOI to the publisher's website.

- The final author version and the galley proof are versions of the publication after peer review.

- The final published version features the final layout of the paper including the volume, issue and page numbers.

Link to publication

\footnotetext{
General rights rights.

- You may freely distribute the URL identifying the publication in the public portal. please follow below link for the End User Agreement:

www.umlib.nl/taverne-license

Take down policy

If you believe that this document breaches copyright please contact us at:

repository@maastrichtuniversity.nl

providing details and we will investigate your claim.
}

Copyright and moral rights for the publications made accessible in the public portal are retained by the authors and/or other copyright owners and it is a condition of accessing publications that users recognise and abide by the legal requirements associated with these

- Users may download and print one copy of any publication from the public portal for the purpose of private study or research.

- You may not further distribute the material or use it for any profit-making activity or commercial gain

If the publication is distributed under the terms of Article $25 \mathrm{fa}$ of the Dutch Copyright Act, indicated by the "Taverne" license above, 


\section{PROJECT MUSE*}

Genomics and the Ark: An Ecocentric Perspective on Human

\section{History}

Hub Zwart, Bart Penders

Perspectives in Biology and Medicine, Volume 54, Number 2, Spring 2011, pp. 217-231 (Article)

Published by Johns Hopkins University Press

DOI: https://doi.org/10.1353/pbm.2011.0019

$\Rightarrow$ For additional information about this article https://muse.jhu.edu/article/429127 


\title{
GENOMICS AND THE ARK
}

\section{an ecocentric perspective on human history}

\section{HUB ZWART* AND BART PENDERS*}

\begin{abstract}
Views of ourselves in relationship to the rest of the biosphere are changing. Theocentric and anthropocentric perspectives are giving way to more ecocentric views on the history, present, and future of humankind. Novel sciences, such as genomics, have deepened and broadened our understanding of the process of anthropogenesis, the coming into being of humans. Genomics suggests that early human history must be regarded as a complex narrative of evolving ecosystems, in which human evolution both influenced and was influenced by the evolution of companion species. During the agricultural revolution, human beings designed small-scale artificial ecosystems or evolutionary "Arks," in which networks of plants, animals, and microorganisms coevolved. Currently, our attitude towards this process seems subject to a paradoxical reversal. The boundaries of the Ark have dramatically broadened, and genomics is not only being used to increase our understanding of our ecological past, but may also help us to conserve, reconstruct, or even revivify species and ecosystems to whose degradation or (near) extinction we have contributed.This article explores the role of genomics in the elaboration of a more ecocentric view of ourselves with the help of two examples, namely the renaissance of Paleolithic diets and of Pleistocene parks. It argues that an understanding of the world in ecocentric terms requires new partnerships and mutually beneficial forms of collaboration and convergence between life sciences, social sciences, and the humanities.
\end{abstract}

${ }^{\star}$ Centre for Society and Genomics (CSG) and Department of Philosophy and Science Studies, Institute for Science, Innovation and Society (ISIS), Faculty of Science, Radboud University, Nijmegen.

tDepartment of Health, Ethics and Society (HES), School of Public Health and Primary Care (CAPHRI), Maastricht University.

Correspondence: Hub Zwart, Institute for Science, Innovation and Society (ISIS), Faculty of Science, Radboud University, PO Box 9010, NL-6500 GL Nijmegen, The Netherlands.

E-mail: h.zwart@science.ru.nl.

The research resulting in this paper is part of the research program of the Centre for Society and Genomics, The Netherlands (CSG), funded by The Netherlands Genomics Initiative (NGI). The authors acknowledge the constructive comments provided by editors and reviewers.

Perspectives in Biology and Medicine, volume 54, number 2 (spring 2011):217-31

(C) 2011 by The Johns Hopkins University Press 


\section{GENOMICS AND THE QUEST FOR SELF-KNOWLEDGE}

In 1990 the Human Genome Project (HGP) was launched as an important historical marker, a pivotal contribution to the time-old quest for human selfknowledge. However, when in 2001 two major publications heralded its completion, it seemed difficult to make out how the desire for self-knowledge had really been furthered by this endeavor (IHGSC 2001; Venter et al. 2001). In various ways mankind seems to stand out from other organisms as a unique type of living entity, developing a critical perspective on its own behavior and consciously engaged in building a complex society of its own making-and therefore increasingly able to determine the conditions of its own evolution. However, this uniqueness is not easily and immediately visible in our genome, which proves to be quite similar to the genomes of other species, such as the mouse and the chimpanzee (Zwart 2007a). Gradually, however, the impact of genomics in general and of the HGP in particular on our self-image is becoming much clearer.

We will argue that this impact is quite substantial. In various ways genomics is now affecting how we see ourselves. What we have in mind is not a return to a view of our genome as a "code" or "book" in which we can decipher who we are, rather, we will explore how genomics is shedding new light on our identity by providing us with novel tools to study human history, in particular early human history. Genomics allows us to analyze, in more detail than ever before, the process of anthropogenesis: the coming into being of humankind. What makes us special (to a certain extent) is the fact that we are not only the outcome of a biological evolution, but also the product of a cultural one. Increasingly, we have been able to transform and shape ourselves by consciously and effectively manipulating our environment, our conditions of existence. Gradually, our natural environment has been complemented or even eclipsed by a sociocultural environment of our own making. To a considerable extent, we can be considered "self-made," and it is the history of this process of self-production that can now be studied in greater detail. Genomics is adding complementary sources of information to established research fields such as paleontology, archaeology, cultural anthropology, and language history.

\section{ThREE PERSPECTIVES ON ANTHROPOgENESIS}

Anthropogenesis refers to the coming into being of mankind, not solely as a biological species, but rather as a being that, unprecedentedly, designs and manages its own environment and influences its own history. Humanity is not only product but also author of its evolution: we have had a conscious and deliberate influence on how our skills, cognitions, and emotions have evolved over time.

Over the centuries, Western views on the process of anthropogenesis have been dominated by three important perspectives. The first was the theocentric perspective, prominent in the Judeo-Christian tradition. The book of Genesis ex- 
emplifies a comprehensive account of the coming into being of mankind through a series of interventions on the part of God as our creator who guides us through history. God created human beings through a separate act of creation, thus setting them apart from other organisms, but also "tended" early human populations as if domesticated. The great Deluge as recorded in Genesis constitutes an act of conscious selection: a small band of individuals with desirable features were singled out, while the rest of mankind was destroyed. Those remaining, found worthy of preservation in the struggle for life, were allowed to re-colonize the world. Their features became a key segment of humanity. Similar acts of intervention are recorded elsewhere in Genesis. Moreover, the carriers of the desired dispositions were explicitly encouraged to reproduce themselves as exuberantly as possible. This pastoral view on anthropogenesis positions God as shepherd in charge of human beings on their way to domestication, transforming them from inhabitants of a forest-like ecosystem called Paradise into responsible and reliable individuals able to function in a well-organized, artificial environment of their own making.

The second perspective has been the humanistic or anthropocentric one. It claims that over and above being a biological species, humans essentially are (and therefore should behave as) autonomous, rational, and moral beings. According to a philosophical tradition of long standing, ranging from Aristotle and Thomas Aquinas up to Immanuel Kant, human existence is characterized by a tension between the Homo naturalis (the biological species within us) and our more rational and civilized self, the Homo rationalis (thinking man) (Taylor 1989). The objective of civilization is to strengthen the rational subject through training and education. This takes place within structures that carry out important functions of discipline and control, such as families, schools, libraries, the army, professional organizations, and, if necessary, prisons - structures that can be grouped together as external providers of population management and supervision (Foucault 1975). Civilization simultaneously takes place through the human individuals themselves, in the context of "practices of the Self" (Foucault 1984), as human beings are constantly improving, training, redefining, and repositioning themselves.

A major weakness of this position is the difficulty of determining convincingly the basis of our unprecedented rationality and autonomy, notably from an evolutionary perspective. The anthropocentric view claims that we are separated from other animals by an insurmountable gap that came into existence due to the development of technology and language, two unique talents of humankind. Though both are connected to biological evolution, through the erect position and development of the human larynx, as a rule the anthropocentric perspective has taken the origins of this human uniqueness as self-evident or pre-given. However, in the light of scientific evidence, it has become increasingly difficult to explain how this uniqueness can be upheld. Philosophers such as Foucault (1966) have argued that this image of man must be regarded as a temporary fiction. In terms of anatomy, physiology, evolution, and genetics, continuity rather 
than discontinuity between humans and other animals appears to be the rule. Additionally, various other animals are involved in practices such as communication and group politics (de Waal 2005; Lieberman 2008). Thus, the anthropocentric view of human beings as autonomous rational agents seems to build on a philosophical fiction: a remnant of the grand theocentric idea that we were created in God's image and are thus equipped with a mysterious core (be it selfconsciousness, freedom, or the soul) that defies scientific exploration and proves accessible through introspection only.

Unsurprisingly, the anthropocentric perspective has increasingly come under siege. A more recent, ecocentric perspective seems more promising, both scientifically and philosophically. It has the potential to revivify the dialogue between the natural sciences and philosophy on what it means to be human. It claims, first of all, that in order to understand anthropogenesis, the history of human beings cannot be studied in isolation from the evolution and history of other species, notably domesticated animals and cultivated plants. Second, it claims that our view of ourselves should build on and "absorb" and reflect new insights made available by scientific research.

In environmental philosophy, building on the work of Leopold (1949), Næss (1989), and others, ecocentrism has already evolved into the dominant position. Journals such as Environmental Ethics and Environmental Values have been launched in order to further develop this view. Similarly, in sociology, the ecocentric worldview ("new ecological paradigm") was proposed by Catton and Dunlap (1980). It not only affects philosophical and sociological positions, however. Increasingly, advancements in dealing with bioinformation, molecular biology and high throughput sequencing are affecting research fields traditionally seen as belonging to the humanities, such as cultural anthropology, philosophical anthropology, and archeology. An important change generated by these cross-fertilizations is that rather than seeing human history predominantly as the narrative of one single species, our history is increasingly being analyzed in terms of evolving manmade ecosystems, comprising a plethora of other species. Molecular anthropology, for instance, shows how genome analysis of current and ancient biological samples may be used, complementary to, or in competition with, paleontology, in order to construct knowledge about hominids and companion species (Stoneking 2008). ${ }^{1}$ Archaeology in the traditional sense (the analysis of inorganic remains, e.g. pottery, tools, weapons, clothing, coins) is complemented by or even giving way to human paleoecology and bioarcheology (the analysis of organic deposits, such as seeds, plants, animals, waste, human remains, and

\footnotetext{
${ }^{1}$ Ever since phylogenetic analysis entered the domain of paleontological research, such competition has been expressed in many forms. While Sarich (1973) argues that "the biochemist knows his molecules have ancestors, while the palaeontologist can only hope that his fossils left descendants," more recently, Zhang and Strasser (2009) have framed phylogenetic analysis as a competition between specimens and sequences.
} 
notably the analysis of ancient DNA; Butzer 1982; Jones 2001). ${ }^{2}$ These developments emphasize that the evolution and history of humanity ought to be regarded as a process of co-evolution, in which various species developed interactive partnerships that have been mutually beneficial to their prospects for survival. Thus, human history must be understood as an evolution of artificial ecosystems involving not only human beings but also the animals and plants they selected and allowed to enter their proverbial "Ark." In the course of history human beings have "invited" a growing number of species to join them on their journey to a new and increasingly man-made environment, a man-made future, indeed-even into a new geological era even that has come to be referred to as the "anthropocene" (Crutzen and Stoermer 2000). ${ }^{3}$

This article elaborates the profile and consequences of this emerging ecocentric perspective on anthropogenesis. We will focus on how insights from genomic research are informing and redefining the ecocentric view of anthropogenesis and point out how taking up an ecocentric perspective not only reframes our vision of our past but is also challenging us to assess and explore our possible future.

\section{EVolution InSide the ARK}

Rather than merely containing a theory, Charles Darwin's On the Origin of Species by Means of Natural Selection (1859) must be seen as the launching of a massive research program that has tremendously affected our view of ourselves and our position vis-à-vis other species. The idea of evolution, however, did not completely erase the conviction that human beings are somehow different-if only because humans are the only species to develop theories concerning their origin at all. This is not to suggest that we have something other animals lack (soul, rationality), but that, more than any other species, we are aware of our history, our evolution, as well as our prospects for the future, positioning ourselves against a much wider temporal horizon and acting accordingly. Therefore, more than other animals, we have had an increasingly significant impact on our own vicissitudes and prospects for survival.

The so-called Neolithic revolution marked the introduction of agriculture (Childe 1936; Harlan 1975). Early agriculture consisted of (1) the creation of artificial environments or ecosystems, initially in the form of small manmade "is-

\footnotetext{
${ }^{2}$ The longest possible life span of DNA in a sample has been calculated at 130,000 years (Kulikov and Poltaraus 2004). However, the function of the genome as a bioarchive, able to contribute to archeology, is not limited to ancient DNA.Via phylogenetic analyses of contemporary DNA samples, bioarcheology probes into the past of man and consort species.

${ }^{3}$ The process of selection we refer to here is not necessarily a conscious process. Species associated with Homo sapiens include various disease-causing bacteria and viruses, as well as parasites. For example, see Kittler, Kayser, and Stoneking (2003) for an analysis of lice as a "domesticated species."
} 
lands" surrounded by natural wilderness; (2) the domestication of a select number of "favorite" animals, greatly influencing their lifestyles, their patterns of behavior, and (eventually) their genomes; (3) the cultivation of a select number of plant forms; and (4) the use of microorganisms for processes of fermentation and food conservation (see, e.g., Abbo et al. 2006; Beja-Pereira et al. 2006; Larson et al. 2007; Mira, Pushker, and Rodríguez-Valera 2006; Saisho and Purugganan 2007). As a result of agriculture, human beings created their own life-world. Rather than being dependent on the food that was provided by natural surroundings, humankind began to produce its own food products and thus to increasingly control its own food policies and intake.

The agricultural village was designed to function as a protective shell and relatively safe haven, allowing its inhabitants to flourish more exuberantly compared to populations that remained "outside" (Mazoyer and Roudart 1997). Nonetheless, in the early days of agricultural settlers, these groups did have to endure famines, starvation, and generally harsh conditions (Ponting 1991). Their situation slowly improved over a long period of time. This has had tremendous consequences. It facilitated exponential population growth, allowing Homo sapiens to dwell on earth in tremendous numbers, affecting and redefining the conditions of life for other species, domesticated as well as undomesticated. There were also consequences for other species immediately involved. While the wild ancestors of horses, camels, mules, and cows more or less went extinct, domestication provided a lifeline for their domesticated descendants, a protective shell safeguarding these "favored races" from extinction, allowing their populations to grow exponentially. Thus, through agriculture, the concept of the Ark migrated from the realm of mythological fiction into the real world of food and labor. The species granted the "privilege" to enter it were safeguarded from decimation, while their wild relatives had to face increasingly hard times, either directly or indirectly threatened in their survival by human beings. Those who did enter the Ark, however, paid a high price for human protection. They became subject to an intense process of transformation, affecting both their phenotype and their genotype, their identity and integrity.

Genomics sheds new light on early human history through the increasing availability of sequenced genomes of cultivated plants and domesticated animals. These genomes, when analyzed with the latest molecular technologies (from structural genomics to systems biology), constitute valuable archives that allow us to reconstruct the emergence and early history of artificial ecosystems. While these ecosystems can be considered manmade, they should equally be considered man-making. They functioned as Arks, or greenhouses, where new varieties of life-forms with promising prospects for the future, including human beings, were gradually cultivated. (For a discussion of the "domestication" of humans, see Leach 2003.) As far as humans were concerned, although training, education, and the trans-generational transmission of information through language and other mnemotechnologies such as writing have played a decisive role, selection 
(through uneven prospects for reproduction) has played a role as well. In ancient rural environments, humans, cultivated plants, and domesticated animals became involved in complex processes of coevolution, mutually beneficial to the various species involved. By intimately intertwining its development with that of other proximate species, humankind has changed the conditions for its evolution. Important chapters of the anthropogenesis narrative and contained in the evolutional history of camels and dogs, and of potato and rice varieties. For instance, the evolution of certain cattle milk protein genes with human lactase metabolism genes can be considered an example of coevolution involving humans and cows, effectively blurring the boundaries between biology and culture (BejaPereira et al. 2003).

In fact, this process started long ago, even before the onset of the Neolithic revolution. Ancient hunters and gatherers managed to survive, not only because of their unique cognitive and communicative qualities as human beings, but also because of the complementary skills and talents of their dogs. Prior to the Neolithic revolution, wolves were gradually domesticated into sledge dogs or pack animals and hunting partners (Verginelli et al. 2006). These domesticated animals significantly increased human mobility and proved outstanding team players. Dogs and humans have to some extent domesticated each other, forging a partnership that was advantageous to both (Schleidt and Shalter 2003). In sum, ecocentric anthropogenesis is a story of intricate pathways of co-evolution, a story which can increasingly be read and deciphered through the use of genomic technologies.

\section{THE EMERGING MULTI-SPECIES ZOOPOLIS: ENLARGING THE ARK}

Those species that were not invited or refused entrance into the Ark had to endure different circumstances during their evolutionary careers. From the earliest stages of human history onwards, long before the introduction of agriculture, mankind has had an impact on the chances for survival of numerous species (Lyons, Smith, and Brown 2004; Pushkina and Raia 2008). In permafrost areas of Northeast Siberia, notably in the Republic of Sakha or Yakutsk, frozen remains of woolly mammoths have been recovered. Their DNA is now being analyzed by researchers, looking for pieces of data that may inform us why this mammal became extinct and what role humans may have played. If the climate change that heralded the end of the Ice Age turns out to be the definitive answer, why did other herbivores survive? And what does "climate change" as commonly understood-a phenomenon resulting from human actions, particularly the release of $\mathrm{CO}_{2}$ through the burning of fossil fuels - have to do with the mammoth's extinction? The answer to these questions will inform how we see our own role in the history of life.

Next to the mammoth, the bison occupies a key position on our track record as an agent of extinction. Recent scholarship (Krech 1999) suggests that the 
emergence of the Great Plains may be partly due to deforestation through pyrotechnology, thus creating conditions favorable to buffaloes and their hunters. This species still roamed the plains of North America in large numbers into the 19th century, when it was almost completely decimated at a devastating pace alongside the flora on which it fed, notably through overhunting with modern rifles. Simultaneously, the Native Americans that had hunted the bison likewise fell victim to the sudden transformation of North America from a largely pre-agricultural territory into a modern industrialized and densely populated nationstate, not only through violence and forced migration but also because they fell victim to epidemics of smallpox and influenza. Recently, sequencing the bison genome has been commenced, for various reasons. First of all, in our effort to save the species from extinction, its genome became "polluted" with cow genes, and it is argued that the bison sequence may allow us to restore the animal's authenticity through conscious selection on the basis of genomic information, ideally in combination with restoring its ecosystem (Halbert and Derr 2007). Moreover, it is argued that the buffalo genome may become an important tool in the future preservation of this species: "managing genomes rather than animals" could be a model for conservation policies of large mammals. As one of the bison conservators argues: "If you don't have the genome, nothing else you do makes a damn difference. ... Species conservation ... is [about] how they are-that's the genome" (Marris 2009, p. 951). Thus, conservation policy is evolving into ecological genome management.

This genomics-based conservation drive may even be taken a step further. Consider, for instance, that the last specimen of the Pyrenean ibex (the wild mountain goat), a species that was once numerous in the border regions of Spain and France, was killed by a falling tree in 2000. Since then, efforts have been made to bring this species back to life. Researchers took adult somatic cell from the tissue of the last specimen and fused them with oocytes from goats that had their nucleus removed. The resultant embryos were transferred into a domestic goat (Capra hircus), to act as surrogate mother. In 2003, the first attempt to clone the Pyrenean ibex failed: only two specimens survived the initial two months of gestation before they died (El Mundo 2003). Six year later, as the result of a second attempt, a single live ibex was born; she died of a lung defect shortly thereafter (Brahic 2009). Nonetheless, it will not seem all that fictitious to expect that somewhere in the near future similar efforts will prove successful. Genomics may increasingly affect our policies for managing (either conserving or restoring) endangered and extinct species that for some reason we want to invite into our Ark. One such reason may be that we feel responsible for having caused its extinction or near extinction in the past.

In addition to transforming the policies of the present, the genomics-based Ark entails a possible scenario that challenges us to reflect on our ecological future. In the light of human history as a backdrop for the present, remarkable reversals seem to be taking place. Our relationships with other species are chang- 
ing fundamentally. On the one hand, in the context of bioindustry and biotechnology, domesticated and cultivated species are being transformed into almost machine-like entities, mere elements within agro-industrial circuits. The animals confined within the Ark have become our prisoners to a much greater extent than ever before. On the other hand, when it comes to managing those species that in the past were denied access to our agricultural ecosystems, there is a tendency to safeguard them from extinction by designing zoo-like environments that are gradually transforming their regimes from detention facilities into wild parks where animals officially selected and identified as "endangered species" are kept alive and are allowed to survive, more or less in combination with their ecosystem, while genome management becomes an important tool for conservation policies to safeguard the authenticity and diversity of populations involved.

A similar change is manifesting itself in our relationship with plants. Ecosystems and agricultural systems are actively being redesigned to be de-domesticated. Thus, while we are opening the doors to the Ark to let more plants and animals in, we are also letting plants and animals out again. We propose to take a closer look at such a reversal in order to demonstrate how our relationships with other species are changing.

\section{genomics of the Palaeolithic Diet}

During and following the Neolithic revolution, our bodies have been exposed to new forms of food intake. Genomic research, especially nutrigenomics, is now claiming that the Neolithic food practices that established themselves in large parts of the world between about 10,000 and 5,000 years ago constituted a deviation from the "natural" human pattern (in a biological sense of the term) that had existed for approximately 96\% of human history (Zwart 2009). Therefore, the food products generated by these "deviant" forms of food production associated with the Neolithic revolution are not in accordance with what, biologically speaking, may be regarded as our natural diet (Eaton and Cordain 1997). From the very start, the new food products (e.g., rice, cereals, potatoes) were neither tailored to our genomes nor to a number of physiological characteristics such as oral ecology, resulting in massive dental pathology in the Neolithic period, including caries, lesions, and tooth loss (Eshed, Gopher, and Hershkovitz 2006). Hence a tension was introduced between our slowly evolving Paleolithic genomes and our suddenly emerging Neolithic lifestyles, between our genomes as the outcome of our biological evolution and our technology-based food regimes as the outcome of a techno-cultural revolution (Richards 2002). The tension between Neolithic diets and Paleolithic genomes has been causing an impressive series of so-called "cultural" health problems, ranging from obesity and diabetes to cardiovascular disease (notably coronary artery disease) and colon cancer (Cordain et al. 2005; Lindeberg et al. 2003; O'Keefe and Cordain 2004). Neolithic diets contain ingredients, moreover, that (for some) are difficult to 
digest, such as gluten. Gluten intolerance, or celiac disease, is basically a Neolithic health problem (Greco 1997). Although the problem emerged about 10,000 years ago, it was only identified as such quite recently through genomics research (Cordain 2006).

Obesity especially is being seen as a typically Neolithic health problem, arising from consuming large quantities of cereals, fat, and other food products made available by agricultural technologies, in combination with the Neolithic habit of settling down and becoming sedentary, of "housing" ourselves and thereby gaining weight. The epidemiological diagnosis of obesity as a public health problem is of a recent date and should therefore be perceived in the context of contemporary sociopolitical and moral contexts-in other words, our effort to distance ourselves from the Neolithic era and its normative ideals, also in terms of body weight (Zwart 2007b). Due to genomic research, we finally begin to understand what we have been doing during the past millennia to our digestive systems and to our bodies by adopting Neolithic lifestyles. ${ }^{4}$

Interdisciplinary collaborations of genomics researchers with archaeologists and paleontologists will perhaps allow them to reconstruct in greater detail what Paleolithic food patterns looked like. Subsequently, it is quite likely that on the basis of this research, our future diets will become increasingly "neo-Paleolithic." New insights in combination with novel technologies may lead to a "renaissance of Paleolithic food' (Muskiet 2005; Zittermann 2003). This will, however, require a revival of many of the food sources that have actively been excluded from the human Ark. While mass production of domesticated plants and crop species has become a possibility precisely because of their domesticated character, the species that contributed to the Paleolithic diet (or, in the future, to the neo-Paleolithic diet) will have to be sought outside of the carefully constructed Ark.

Promoting a return to a more Paleolithic diet more congenial to our genome, however, may come down to regarding the human genome in a far too deterministic manner, as a largely inflexible entity. Yet, it is becoming increasingly clear that even from a genomics perspective human life and health must be seen as the outcome of a complex interaction between genome, lifestyle, and environment, while "epigenomics" is studying the ways in which actual lifestyles are affecting our genome, which continues to change and respond, even during our individual lifetime (Bonetta 2008). Such changes can subsequently acquire a heritable character (Jablonka and Lamb 2008). This flexibility suggests that neo-Paleolithic

\footnotetext{
${ }^{4}$ Consider, for instance, increased documentation on lateral (or horizontal) gene transfer between food genomes and human genomes through retroviral involvement and transposable elements (Panoff and Chuiton 2004). This is changing who we are on a genomic level and gives an entirely new, ecocentric meaning to the adage "you are what you eat." Spetz (2003) even argues that "a fairly large part of the human genome is actually composed of retroviral genes: it can be hard to imagine that we are actually large walking carriers of fossil retroviral genes" (p. 2821).
} 
diets may look much less like Paleolithic ones than might be expected from a purely historical perspective.

\section{CONCLUSION}

As indicated, various efforts have already been invested in applying genomics to deepen our understanding of past relationships between humans and other species. Similarly, various attempts have been made to unravel the ties between diets and genomes and even to make our food intake more "Paleolithic" once again, so that our genomes and our lifestyles may more perfectly match one another. They represent our desire to reconsider and redraw the boundaries of the Ark which, during the past millennia, came to be so carefully constructed. Species that have been relentlessly domesticated, such as the primeval cow or aurochs (Bos primigenius), are gradually reverted into their wild type kin, while wild parks are being set up to allow both animals and vegetation to roam and flourish relatively freely once again. The rain forest is being protected (albeit not yet very successfully) to sustain biodiversity, and organic farming is rediscovering plant species long lost.

Thus, the sphere of the proverbial Ark, the radius of our responsibility, is significantly broadening. We feel responsible for many forms of life whose prospects of survival have been affected by Homo sapiens, and the human sphere of influence is extending dramatically beyond its traditional boundaries far "into the wild." In the end, the human Ark may encompass all species officially registered as "endangered," in combination with a growing number of formerly extinct ones as well. Initially, the Ark exemplified a gesture of differentiating and distancing ourselves from nature as an unfriendly, unreliable and threatening environment. At present, the shifting boundaries of the Ark reflect the same increase in scale that is discernable in the development of the rural farms and villages into the metropolises of today. As the Ark is significantly expanding, introvert anthropocentrism has given way to extrovert ecocentrism, and to what seems to be a new covenant between nature and society.

Indeed, the changing relationships described above are expressions of a changing view of our own position in the world. We have left theocentric and anthropocentric perspectives behind. Narratives of servitude and rule are being replaced with narratives of care. We are entering a more ecocentric perspective that acknowledges the extent to which the vicissitudes of humans and other species mutually affect the prospects of survival for all, including ourselves. This novel view not only builds on but also significantly affects and inspires our scientific inquiries into this evolving world. It generates questions that transcend the traditional division between biology, sociology, and philosophy, dealing with such subjects as diets and species conservation as simultaneously biological, social, and moral issues. 
The many variants of genomic inquiry, from large-scale sequencing initiatives up to nutrigenomics, are emphatically directing their gaze beyond the traditional boundaries of the Ark. In the context of the breeding of plant forms such as potato or tomato, for example, genomic inquiry is exploring the possibilities of using the genomes of ancient varieties (wild-type ancestors of existing crops, such as primeval tomatoes and potatoes that once existed on the slopes of the Andes) in order to produce more healthy, tasty and resilient tomatoes in the future, providing a better match for our genomes. Step by step, we are expanding our horizon, in order to reintroduce bits of history into the present. This not only applies to plants, but to animals as well, eventually resulting in the resurrection of extinct populations by reconstructing their DNA, from the Pyrenean ibex to the mammoth genome (Folch et al. 2009; Miller et al. 2008). In theory, it is not impossible that one day revivified mammoths will wander through reconstructed Siberian environments as similar as possible to the Pleistocene conditions of former times ("Pleistocene Parks"). Nevertheless, what may appear as "reversals" in our relationship with companion species may in fact represent the opposite: an intensification of our grasp on their biological fates through genome management.

Managing our future as a species and as a society presents us with a plethora of questions. These are neither purely biological questions, nor solely philosophical or ethical ones. And this has consequences for the way in which our inquiries and deliberations are to be organized. Redrawing the boundaries of the Ark inevitably requires (and enables) a redrawing of the traditional boundaries between the life sciences, the social sciences and the humanities. In various circles, inter-, multi-, cross-, supra-, pluri-, and trans-disciplinarity have been put firmly on the agenda (see, e.g., Hessels and van Lente 2008). The need to overcome boundaries between traditional disciplines is being recognized on the applied level (in the context of concrete ecological problems, for instance), as well as on the fundamental level. New forms of bioinformation are produced in the context of newly emerging research fields that are likely to affect and inform our policies in the area of health, food, and the environment and that will shape our future lives. When it comes to retracing the history and exploring the possible futures of mankind in an ecocentric manner, a comprehensive collaboration that combines biological, sociocultural, and bioethical forms of expertise is required.

On the basis of emerging bioarchives that are now becoming available, a complex and comprehensive narrative is developing concerning the past history and possible future of human existence. These bioarchives not only allow us to reconstruct and even resurrect extinct species, but also incite us to redefine the relationship between science, society, and the self-that is, between the biological, the political, and the moral dimensions of human activity. Therefore, the art of reading and writing bioarchives requires broader, supra-disciplinary forms of expertise and collaboration. In such a collaboration, "things are literally done 
together ... the scientist discovers how much philosophy there is in biology ... and the philosopher discovers that one needs to become a biologist to reflect upon what is happening in the world" (Penders et al. 2008, p. 711).

\section{REFERENCES}

Abbo, S., et al. 2006. The ripples of "the big (agricultural) bang": The spread of early wheat cultivation. Genome 49(8):861-63.

Beja-Pereira, A., et al. 2003. Gene-culture coevolution between cattle milk protein genes and human lactase genes. Nat Genet 35(4):311-13.

Beja-Pereira, A., et al. 2006. The origin of European cattle: Evidence from modern and ancient DNA. Proc Natl Acad Sci USA 103(21):8113-18.

Bonetta, L. 2008. Epigenomics: Detailed analysis. Nature 454:795-98.

Brahic, C. 2009. Extinct animal cloned for the first time. New Sci (Feb. 2).

Butzer, K. 1982. Archaeology as human ecology. Cambridge: Cambridge Univ. Press.

Catton, W. R., and R. E. Dunlap. 1980. A new ecological paradigm for post-exuberant sociology. Am Behav Sci 24(1):15-47.

Childe, V. G. 1936. Man makes himself. London: Watts.

Cordain, L. 2006. Implications of Plio-Pleistocene hominin diets for modern humans. In Early hominin diets: The known, the unknown, and the unknowable, ed. P. Ungar, 363-83. Oxford: Oxford Univ. Press.

Cordain, L., et al. 2005. Origins and evolution of the Western diet: Health implications for the 21st century. Am J Clin Nutr 81:341-54.

Crutzen, P., and E. Stoermer. 2000. The “anthropocene.” IGBP Newsletter 41:17-18.

Darwin, C. 1859. On the origin of species by means of natural selection, or the preservation of favoured races in the struggle for life. Repr. New York: Gramercy, 1995.

de Waal, F. 2005. A century of getting to know the chimpanzee. Nature 437:56-59.

Eaton, S. B., and L. Cordain. 1997. Evolutionary aspects of diet: Old genes, new fuels. In Nutrition and fitness: Evolutionary aspects, children's health, programs and policies, ed. A. P. Simopoulos, 26-37. Basel: Karger.

El Mundo. 2003. Fracasa la primera clonación de un animal extinto en España. July 7.

Eshed, V., A. Gopher, and I. Hershkovitz. 2006. Tooth wear and dental pathology at the advent of agriculture: New evidence from the Levant. Am J Phys Anthropol 130(2): $145-59$.

Folch, J., et al. 2009. First birth of an animal from an extinct subspecies (Capra pyrenaica pyrenaica) by cloning. Theriogenology 71(6):1026-34.

Foucault, M. 1966. Les mots et les choses: Une archéologie des sciences humaines. Paris: Gallimard.

Foucault, M. 1975. Surveiller et punir: Naissance de la prison. Paris: Gallimard.

Foucault, M. 1984. Le souci de soi: Histoire de la sexualité 3. Paris: Gallimard.

Greco, L. 1997. From the neolithic revolution to gluten intolerance: Benefits and problems associated with the cultivation of wheat. J Pediatr Gastroenterol Nutr 24(S1):1417.

Halbert, N., and J. Derr. 2007. A comprehensive evaluation of cattle introgression into US federal bison herds. J Hered 98:1-12. 
Harlan, J. R. 1975. Crops and man. Madison, WI: American Society of Agronomy.

Hessels, L. K., and H. van Lente. 2008. Re-thinking new knowledge production: A literature review and a research agenda. Res Policy 37:740-60.

International Human Genome Sequencing Consortium (IHGSC). 2001. Initial sequencing and analysis of the human genome. Nature 409:860-921.

Jablonka, E., and M. Lamb. 2008. Soft inheritance: Challenging the modern synthesis. Genet Mol Biol 31(2):389-95.

Jones, M. 2001. The molecule hunt:Archaeology and the search for ancient DNA. London: Allen Lane.

Kittler, R., M. Kayser, and M. Stoneking. 2003. Molecular evolution of Pediculus humanus and the origin of clothing. Curr Biol 13(16):1414-17.

Krech, S. 1999. The ecological Indian: Myth and history. New York: Norton.

Kulikov, E. E., and A. B. Poltaraus. 2004. Ancient DNA, paleogenomics, and anthropogenesis. Mol Biol 38(4):623-24.

Larson, G., et al. 2007. Ancient DNA, pig domestication, and the spread of the Neolithic into Europe. Proc Natl Acad Sci USA 104(39):15276-281.

Leach, H. M. 2003. Human domestication reconsidered. Curr Anthropol 44(3):349-68.

Leopold, A. 1949. A Sand County almanac. Repr. New York: Ballantine Books, 1970.

Lieberman, B. 2008. Details of being human. Nature 454:21-23.

Lindeberg, S., L. Cordain, and S. B. Eaton. 2003. Biological and clinical potential of a paleolithic diet. J Nutr Environ Med 13(3):149-60.

Lyons, S. K., F. A. Smith, and J. H. Brown. 2004. Of mice, mastodons and men: Humanmediated extinctions on four continents. Evol Ecol Res 6(3):339-58.

Marris, E. 2009. The genome of the American West. Nature 457:950-52.

Mazoyer, M., and L. Roudart. 1997. Histoire des agricultures du monde, du Néolithique à la crise contemporaine. Paris: du Seuil.

Miller, W., et al. 2008. Sequencing the nuclear genome of the extinct woolly mammoth. Nature 456:387-90.

Mira, A., R. Pushker, and F. Rodríguez-Valera. 2006. The Neolithic revolution of bacterial genomes. Trends Microbiol 14(5):200-206.

Muskiet, F. A. J. 2005. Evolutionaire geneeskunde: U bent wat u eet, maar u moet weer worden wat $\mathrm{u}$ at. [Evolutionary medicine: You are what you eat, but you should be what you ate]. Ned Tijdschr Klin Chem Labgeneeskd 30:163-84.

Næss, A. 1989. Ecology, community and lifestyle. Cambridge: Cambridge Univ. Press.

O'Keefe, J. H., and L. Cordain. 2004. Cardiovascular disease resulting from a diet and lifestyle at odds with our Paleolithic genome: How to become a 21st-century huntergatherer. Mayo Clin Proc 79:101-8.

Panoff, J.-M., and C. L. Chuiton. 2004. Horizontal gene transfer: A universal phenomenon. Hum Ecol Risk Assessment 10(5):939-43.

Penders, B., K. Horstman, and R.Vos. 2008. A ferry between two cultures: Crafting a profession at the intersection of science and society. EMBO Rep 9(8):709-13.

Ponting, C. 1991. A green history of the world. New York: Penguin.

Pushkina, D., and P. Raia. 2008. Human influence on distribution and extinctions of the late Pleistocene Eurasian megafauna. J Hum Evol 54(6):769-82.

Richards, M. P. 2002. A brief review of the archaeological evidence for Palaeolithic and Neolithic subsistence. Eur J Clin Med 56(12): 1270-78. 
Saisho, D., and M. D. Purugganan. 2007. Molecular phylogeography of domesticated barley traces expansion of agriculture in the old world. Genet Mol Biol 177(3):1765-76.

Sarich,V. M. 1973. Just how old is the hominid line? Yearbook Phys Anthropol 17:98-112.

Schleidt, W. M., and M. D. Shalter. 2003. Co-evolution of humans and canids: An alternative view of dog domestication: Homo homini lupus? Evol Cogn 9(1):57-72.

Spetz,A.-L. 2003. Lateral gene transfer in the genomic era: Lateral DNA transfer-mechanisms and consequences. J Cell Sci 116(14):2821.

Stoneking, M. 2008. Human origins: The molecular perspective. EMBO Rep 9(suppl.1): S46-S50.

Taylor, C. 1989. Sources of the self: The making of the modern identity. Cambridge: Cambridge Univ. Press.

Venter, J. C., et al. 2001. The sequence of the human genome. Science 291(5507):1304-51.

Verginelli, F, et al. (2006). Domesticazione ed evoluzione dei cani: Dati genetici, archeozoologici e ruolo del DNA antico. [The origins of dogs: archaeozoology, genetics, and ancient DNA]. Med Secoli 18(3):741-54.

Zhang, G., and B. J. Strasser. 2009. Specimens versus sequences. Science 323(5922):1672.

Zittermann, A. 2003. Aktuelle Ernährungsempfehlungen vor dem Hintergrund prähistorischer Ernährungsweise. [Dietary recommendations in the light of prehistoric diets]. Ernährungs Umschau 50(11):418-25.

Zwart, H. A. E. 2007a. Genomics and self-knowledge: Implications for societal research and debate. New Gen Soc 26(2):181-202.

Zwart, H. A. E. 2007b. Slankheid als beschavingsoffensief: De culturele en maatschappelijke betekenis van obesitas. In De obesogene samenleving: Maatschappelijke perspectieven op overgewicht, ed. H. Dagevos and G. Munnichs, 43-51. Amsterdam: Amsterdam Univ. Press.

Zwart, H. A. E. 2009. Biotechnology and naturalness in the genomics era: Plotting a timetable for the biotechnology debate. J Agric Environ Ethics 22(6):505-29. 